\title{
Effects of Feeding Some Herbs on Hyperuricemic Rats
}

\author{
Walaa I.M. Aniess
}

Home Economic Dept., Fac. of Specific Education, Ain-shams University

\section{ABSTRACT}

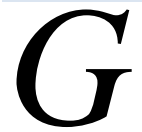

out is an inflammatory joint disorder characterized by hyperuricaemia and precipitation of monosodium urate crystals in the joints. This study aimed to discover the beneficial effects of feeding cinnamon or / and ginger, as a powder form, on the consequence symptoms of gout on induced hyperuricemic rats. Forty nine male albino rats weighing $192 \pm 23 g$ were divided into 7 equal groups; negative control group fed on standard diet only, while the other 6 experimental groups were injected orally with ethanol (1.8g per kilogram of body weight) every 24 hour for eight days to induce hyperuricemia, after confirmation they fed on standard diet only (positive control) or with adding $1 \%$ \& $2 \%$ ginger, $1 \%$ \& $2 \%$ cinnamon and mixture of $1 \%$ ginger $+1 \%$ cinnamon of total diet weight for continued four weeks after adaptation period. Serum uric acid, urea and creatinine, serum liver enzymes (AST, ALT, and ALP) activities, total protein, serum albumin and globulin levels were determined. Results revealed that supplementations with ginger, cinnamon or their mixture for hyperuricemic rats diets; declined the feed efficiency ratios, while increased relative weight of liver and kidneys significantly $(p<0.05)$ ameliorated proportionally with the level of adding, also increments of uric acid, urea and creatinine levels were decreased significantly, furthermore decreased the raised serum levels of ALT, AST \& ALP enzymes' activities and ameliorated significantly the documented decrements in the levels of serum total proteins and albumin comparing with positive control group. Histopathological kidneys' investigation revealed that higher supplementations with $2 \%$ ginger, cinnamon or their mixture groups modulate all undesirable changes recorded in kidneys of positive control group. These outcomes could mention that using ginger and cinnamon may improve kidney functions, liver enzymes and protein fractions, especially the mixture of them which was the most beneficial effects recorded; it could be used as hypouricemic agent and adjuvant treatment for gout disease.

Key words: Ginger, Cinnamon, Nutrition, Hyperuricemia, Rats, Liver enzymes, Kidney functions and protein fractions. 
Walaa I.M. Aniess

\section{INTRODUCTION}

Uric acid is a final enzymatic product in the degradation of purine nucleosides, and it has the ability to scavenge oxygen radicals and protect the erythrocyte membrane from lipid oxidation. Uric acid is produced by xanthine oxidase from xanthine and hypoxanthine, which in turn are produced from purine. Uric acid is more toxic to tissues than either xanthine or hypoxanthine. A xanthine oxidase inhibitor is any substance that inhibits the activity of xanthine oxidase, an enzyme involved in purine metabolism. In humans, inhibition of xanthine oxidase reduces the production of uric acid (Pacher et al., 2006).

In most other mammals, the enzyme uricase further oxidizes uric acid to allantoin. The loss of uricase in higher primates parallels the similar loss of the ability to synthesize ascorbic acid (Proctor, 1970). Both uric acid and ascorbic acid are strong reducing agents (electron donors) and potent antioxidants. In humans, over half the antioxidant capacity of blood plasma comes from uric acid. About $70 \%$ of daily uric acid disposal occurs via the kidneys and in 5-25\% of humans impaired renal excretion leads to hyperuricemia (Vitart et al., 2008).

Hyperuricemia is the major and primary risk factor of symptomatic gout, the clinical significance of which has been identified as the development of various comorbidities, including gout metabolic syndrome, coronary artery disease and type-2 diabetes, despite its major antioxidant

property

(Changgui et al., 2013). There are many factors that contribute to hyperuricemia including obesity, insulin resistance, alcohol consumption, diuretic use, hypertension, renal insufficiency and genetic 
Walaa I.M. Aniess

makeup... etc. Of these, They are paradoxically alcohol (ethanol) is the most opposing under different important, which enhances experimental conditions. Uric adenine nucleotide degradation and increases lactic acid level in blood, leading to hyperuricemia (Tetsuya et al., 2005).

Elevated serum uric acid (hyperuricemia) can result also from high intake of purine-rich foods or high fructose intake (Tausche et al., 2006). Excess serum accumulation of uric acid, which could lead to a type of arthritis known as "Gout" is nine times more common in men than in women (Heinig and Johnson, 2006). It predominantly attacks males after puberty, with a peak age of 75 , while in women gout attacks usually after menopause. Also, Yuri et al., (2011) reported that biological effects of uric acid, generated in the human body either from food or resulting from the purine degradation pathway via xanthine oxidoreductase, are extremely pleiotropic. acid is a powerful signaling molecule that can affect intracellular signal transduction, leading to oxidant production via nicotinamide adenine dinucleotide phosphate (NADPH) oxidase and expression of proinflammatory mediators.

Medicinal plants are important for pharmacological research and drug development, one fifth of all the plants found in India are used for medicinal purpose. Out of these the bark of "Cinnamon" is widely used as a spice due to its distinct odor of essential oils. Main chemical constituents are Cinnamic acid, Cinnamaldehyde, Euginol, and essential oils (Vaibhavi et al., 2010). Cinnamaldehyde may be a potential lead compound for developing the pharmaceutic of anti- 
hyperuricemia agent (Wang $\boldsymbol{e t}$ al., 2008).

Polyphenols, which are among the natural dietary antioxidants found in cinnamon, have been shown to reduce oxidative stress in a dose-dependent manner via the inhibition of 5lipoxygenase. Specific antioxidant phytochemicals that have been identified in cinnamon include epicatechin, camphene, eugenol, gammaterpinene, phenol, salicylic acid and tannins. Today, natural antioxidants are the focus of considerable attention and efforts are ongoing for the replacement of synthetic ones. In addition, these natural antioxidants can be formulated as functional foods and can help prevent oxidative damage from occurring in the body (Hamidpour et al., 2015).

Zingiber officinal Roscoe (Ginger) is an indispensable component of curry, belongs to the Zingiberaceae family. Ginger has been used to treat a number of diseases; including headache, cold, arthritis, renal function, and reduces serum creatinine, urea, and Blood urea nitrogen (BUN). The mechanisms of these renoprotective effects may involve both oxidative stress reduction and significant 6gingerol antioxidant effects too (Mahmoud et al., 2012).

Therefore, the present study was carried out to investigate the effects of feeding two doses of cinnamon, ginger or their mixture supplementations on induced hyperuricemia in albino rats.

\section{MATERIALS \& METHODS \\ Materials}

Cinnamon and ginger powders were obtained from the Agriculture Seeds, Herbs and Medicinal Plants Company, Cairo, Egypt, and used individually or combined in rats, feeding as hyperuricemic treatments. Basal diet used was prepared according to Jerome et al., 
(2002), while the composition of minerals mixture used was according to Hegested et al., (1941) and the vitamins mixture used was that of Campbell, (1963). Ethanol has been used to induce hyperuricemia according to Faller and Fox, (1982), which obtained as liquid chemical from "Elgomhoria" Company, $\mathrm{C}$ a i r o, E g y $\mathrm{pt}$.

Forty nine male albino rats, Sprague Dawley strain, of mean body weight $192 \pm 23 \mathrm{~g}$ were obtained from the laboratory animal house of Ophthalmic Research Institute, Giza, Egypt. Animals were acclimatized to laboratory condition before experimental applying and fed on basal diet and water adlibitum.

\section{Methods}

Adapted rats were divided into seven equal groups; first group (7rats) was normal rats fed on basal diet only and served as negative control. While the remaining
(42 rats) administered orally the ethanol (1.8 g per kilogram of body weight) every 24 hours for eight days to induce hyperuricemia according to Faller and Fox, (1982). Ethanol, 50\%, increases urate synthesis by enhancing the turnover of adenine nucleotides. Hyperuricemia was confirmed after orally swallowed, and then rats were divided into six groups (7rats/group) and fed on: basal diet only (Positive control) or with additives; $1 \%$ cinnamon or ginger or $2 \%$ cinnamon or ginger or combination of them equally as $2 \%$ of total diet weight for four continued weeks. Quantities of consumed diet and waste were recorded daily, also rats' weight assessed weekly and feed efficiency ratio (FER) were calculated according to Chapman et al., (1959).

Four weeks later, blood samples were collected from hepatic portal vein and centrifuged for 10 minutes at 3000 revolutions per minute 
Walaa I.M. Aniess

"r.p.m." to separate the serum from fasted rats and kept frozen at $-20{ }^{\circ} \mathrm{C}$ till analysis for;

- Liver enzymes activity: Serum

Aspartate

Aminotransferase

(AST) and serum Alanine

Aminotransferase (ALT) were determined according to Reitman and Frankel, (1957).

While Serum Alkaline Phosphatase

(ALP) was performed according to the method of Roy, (1970).

- Kidney functions: Serum uric acid was determined according to the method described by Barham and Trinder, (1972) and Fossati et al., (1980), while urea was determined according to Kaplan, (1984), but serum creatinine was assessed according to the reaction described by Faulkner and King (1976).

- Serum Proteins: Total protein was estimated as described by Sonnenwirth and Jaret, (1980), while albumin was determined according to Drupt, (1974). While globulin was calculated according to the equation described by Chary and Sharma, (2004); Globulin $(\mathrm{mg} / \mathrm{dl})=$ Total protein $(\mathrm{mg} / \mathrm{dl})$ Albumin (mg/dl).

Livers, hearts and kidneys were removed and washed with saline solution and dried then weighted for relative weight of organs calculation, then kidneys were kept in buffered formalin solution $(10 \%)$ for histopathological examinations according to Drury and Wallington, (1980). 
Walaa I.M. Aniess

Statistical analysis

Data obtained were statistically analyzed using computer program of Statistical Analysis System "SAS". The results were expressed as mean \pm standard deviation "SD" and tested for significance using one way ANOVA, Duncan test at a probability $\quad \mathrm{P} "<0.05$, according to Armitage and Berry, (1987).

\section{RESULTS \& DISCUSSION}

Data presented in table (1) shows that body weight gain (BWG \%) of hyperuricemic (positive control) group declined about $40.6 \%$ of negative control one. On the other hand, treated groups received supplemented diet with cinnamon or the mixture of it with ginger showed significant decrements in $\mathrm{BWG} \%$ compared with the positive and negative control groups, while rats received supplemented diet with both gingers' ratios recorded insignificant decrements with positive control group.
Regarding to the same table feed efficiency ratio (FER) showed that there were significant decrements for all groups comparing with negative control, while supplementations with ginger or cinnamon or their mixture for introduced diet declined more the FERs of the hyperuricemic rats, especially cinnamon and the mixture which were significant than ginger.

These results were in agreement with Saravanan et al., (2014) and Shalaby\& Saifan, (2014), who documented that cinnamon and ginger extracts exhibited anti obesity and hypolipidemic effects in obese rats. They elucidated that the possible potential mechanism underlying the hypolipidemic effect of them could be due to their high contents of polyphenols (cinnamon) and of gingerols and shogaols (ginger), which inhibit the intestinal absorption of cholesterol with subsequent 
Walaa I.M. Aniess

hypocholesterolemic activity. Also, cinnamon contains choline, which helps the body metabolize fats, makes up a part of healthy cell membranes and helps drive a number of chemical reactions within cells according to Vangalapati et al., (2012).

On the other hand, Giner and Meguid, (1993) mentioned that $3 \%$ ethanol solution provided $19 \mathrm{kcal}$ /day, which was equivalent to about $50 \%$ of the daily caloric intake of the rats. So that, ethanol significantly decreased food intake, irrespective of the route administered, but this reduction in feed intake did not result in a calorie-tocalorie compensation. Instead, providing $50 \%$ of calories as $3 \%$ ethanol via the intragastric route led to a $16 \%$ reduction in feed intake, while only a $9 \%$ reduction in feed intake occurred when the $3 \%$ ethanol solution was given intravenously. Also, Klesges et al., (1994) found that alcohol also appears to increase metabolic rate significantly, thus causing more calories to be burned rather than stored in the body as fat.

Data presented in Table (2) showed that oral administration with ethanol $1.8 \mathrm{~g} / \mathrm{kg}$ b.w. every $24 \mathrm{hr}$. for eight days led to significant increments $(p<0.05)$ in liver, heart and kidneys weight / body weight $\%$ as compared to healthy rats. Treatments with ginger or cinnamon or their mixture ameliorated significantly these increments. Regarding to relative weight of liver and kidneys, cinnamon was more effective in this amelioration than ginger, which was directly proportional with the level of adding, while the mixture of them was the most pronounced amelioration.

Also, the significant enlargement documented in positive control group for heart's relative weight was ameliorated significantly $(\mathrm{p}<0.05)$ in all treated groups, 
Walaa I.M. Aniess

but ginger was more effective than cinnamon, the mixture of them was the most pronounced amelioration too. As reported by Mathew and Abraham, (2006) and Kim et al., (2005), ginger and cinnamon have highly antioxidant properties, therefore they may show significant amelioration for the relative weight of enlarged organs.

In investigation by Tariq et al., (2008) for the effects of different doses of ethanol on body organs of Japanese quails, results at the end of 4th week revealed a significant effect on relative weight of heart, kidney and lungs in most treated groups. The increase in heart and lung weight was significant in quail given $4 \%$ and higher ethanol, of kidney given 2 to $8 \%$ ethanol, while statistically no effect was observed on relative weight of liver.

Data listed in table (3) focused on serum uric acid, urea and creatinine of hyperuricemic rats fed on different ratios of ginger or cinnamon or combination of them. It is clear that serum levels of uric acid, urea and creatinine of positive control group were raised significantly $\quad(p<0.05) \quad$ after ethanol treatment comparing with negative control group. While, all treated groups with the herbs had decrements in the serum levels of all parameters mentioned above compared to positive control group.

Cinnamon and ginger mixture group was the most pronounced amelioration founded for kidneys' functions indicators; uric acid and urea levels in hyperuricemic rats groups. While the best treatment for the raised creatinine level was found in that group which treated with cinnamon $2 \%$.

Cinnamon contain cinnamaldehyde that may be a potential compound for developing the pharmaceutics of anti-hyperuricemia agent as 
Walaa I.M. Aniess

mentioned by Wang et al., (2008), who studied the effect of essential oil from leaves of Cinnamomum osmophloeum acts as a xanthine oxidase inhibitor and reduces the serum uric acid levels in oxonate-induced mice. Moreover, Tanomand and Najafian, (2013) assessed the inhibitory effects of cinnamon extract on gentamicin-induced nephrotoxicity in male adult wistar rats. The results showed that using cinnamon is effective in decreasing blood urea nitrogen, serum creatinine and uric acid in gentamicin - induced nephrotoxicity, so that further improvements can be seen at higher doses. Due to the low cost of Cinnamon, ease of use and minimal side effects seem to be less gentamicin as an adjuvant treatment in order to minimize damage to the kidney.

For the other herb, Iroaganachi et. al, (2015) recorded that ginger supplementation for male albino rats with renal dysfunction significantly decreased both serum urea and creatinine levels of rats compared with positive control rats.

Ginger significantly reduces serum uric acid, urea and creatinine, the mechanisms of these renoprotective effects may be outcomes of both oxidative stress and 6-gingerol, which demonstrated significant antioxidant effects as recorded by Mahmoud et al., at (2012), who evaluated the effects of Zingiber officinale Roscoe (Ginger), Arabic gum (AG) and Boswellia on both acute and chronic renal failure (CRF) and the mechanisms underlying their effects. Ginger and AG showed renoprotective effects in both models of renal failure. Ginger was more potent than $A G$ in both models of renal failure. They mentioned also that oral administration of ginger along with adenine caused a significant improvement in 
Walaa I.M. Aniess

renal function, represented by the significant decrease in serum creatinine, urea, and BUN. Finally, they documented that ginger and AG could be beneficial adjuvant therapy in patients with acute renal failure and CRF to prevent disease progression and delay the need for renal replacement therapy.

These results are agreed with those findings of Chyntiadewi, (2011), who investigate the effect of ginger's rhizome in decreasing uric acid level in hyperuricemic rats, which induced by giving goat's brain during eight days. Three different dosages; 5, 10 and $20 \%$ of ginger's rhizome were added for diets of hyperuricemic rats. After fourteen days results showed that ginger's rhizome can decrease uric acid level in these rats. He elucidated that decrement of uric acid level for the active compounds in ginger's rhizome; glycine, ascorbic acid, and fiber that have uricosuric effect and hypouricemia.

Data in Table (4) demonstrated the activity of liver enzymes for hyperuricemic rats as affected by herbs feeding. It could be noticed that ethanol treatment significantly $(p<0.05)$ increased ALT, AST and ALP enzymes in the serum of positive control group as compared to negative control one. While treated groups significantly $(p<0.05)$ decreased the raised serum levels of ALT and AST activities when compared to positive control group. Treated groups with the two herbs at $2 \%$ additions and their mixture recorded also significant $(p<0.05)$ decrements in serum level of ALP enzyme as compared to the positive control one.

Treated group with the mixture of herbs showed the highest decrements in AST and ALP enzymes activity levels of serum compared to positive control group. While, 
Walaa I.M. Aniess

Ginger1 \% showed the highest decrement in ALT enzyme level of the serum compared to positive control group.

These findings agreed with Askari et. al, (2014), who documented that supplementation with 1500 mg powdered cinnamon daily/ 12 weeks decreased significantly ALT \& AST in patients with nonalcoholic fatty liver disease. The possible mechanism of this activity for cinnamon may be due to free radical-scavenging polyphenols compounds.

The hepatoprotective properties were documented by Moselhy and Ali at (2009), who studied the hepatoprotective activity of aqueous and ethanolic extracts of cinnamon against carbon tetrachloride (CC14) induced lipid peroxidation and hepatic injury in rats. The results obtained indicated that ethanolic extract has more potent hepatoprotective action than water extract against $\mathrm{CC} 14$ by lowering the malondialdhyde (MDA) level and elevating antioxidants enzymes activities; superoxide dismutase (SOD) and catalase (CAT).

On the other hand, Sabina et. al, (2011) deduced that 6-gingerol, an active ingredient of ginger, treatment to acetaminophen-induced hepatotoxicity in mice showed significant hepatoprotective effect by lowering the hepatic marker enzymes (AST, ALT, and ALP) and total bilirubin in serum $(\mathrm{P}<0.05)$. In addition, it prevented the elevation of hepatic malondialdehyde formation and the depletion of antioxidant status in the liver. Ginger also has been reported to exhibit antioxidant potential and hepatoprotective activity as recorded by Liu et al., (2013), who assessed the effects of ginger essential oil against alcoholic fatty liver disease in mice. Treatment with ginger essential oil administered every day for 4 weeks exhibited hepatoprotective activity. 
Also in a study by Shalaby and Saifan, (2014), revealed that cinnamon and ginger significantly reduced body weight gain and body fat mass, normalized serum levels of liver enzymes, also increased activity of kidney antioxidant enzymes, improved lipid fractions, decreased blood glucose and leptin, and increased insulin serum levels in obese diabetic rats.

Data listed in Table (5) showed the serum proteins of hyperuricemic rats as affected by feeding on the studied herbs. It is clear that the serum levels of total protein (T.P) and albumin (Alb.) of positive control group significantly decreased than negative control group, while globulin (Glb.) were insignificantly differed. Treatments for experimental groups with the studied herbs and their mixture ameliorated these decrements significantly $(p<0.05)$ in the levels of serum total proteins, while significances were only in groups fed on ginger $1 \%$ and cinnamon $2 \%$ and their mixture for the levels of albumin. No significance changes were recorded for serum levels of globulin in all treated groups compared with positive control group.

These results were in agreement with Kanani et. al, (2014), who documented that globulin increased significantly with ginger supplementation ( $1 \%$ ) after 60 days of feeding for fisht. Also, Oso et. al, (2013) confirmed that feeding dried ginger meal for keets 28-dayold male for 56 days increased total serum protein and srum albumin significantly $(\mathrm{P}$ $<0.05$ ).

Results were in harmony with a similar study by ALGhwij et al., (2012), who investigated the protection effect of Curcumin (CCM), Cinnamon (CNN) and Ginger (GE) against trichloroethylene (TCE)induced hepatotoxicity and to 
Walaa I.M. Aniess

demonstrate its possible mode of action. The results showed that serum total protein did not changed in animals fed on $\mathrm{CCM}$ and $\mathrm{CNN}$ alone than that of normal ones. On adding of Herbal plants to TCE treatment, serum total protein was partially ameliorated with CCM and CNN. On the other hand, no significant changes were observed in rats treated with TCE/GE. On adding of herbal plants to TCE treatment, serum albumin was partially ameliorated with $\mathrm{CCM}$ and GE. On the other hand, no significant changes were observed in rats treated with TCE/CNN because the measurement of serum ALAT and albumin are more from the intestine.

\section{Histopathological}

\section{investigations:}

It could be noticed in photos 2 \& 3 that ethanol treatment showed vacuolation at renal tubular epithelium and perivascular inflammatory cells infiltration, also showed protein cast in the lumen of renal tubules in rats' kidneys compared with normal rats in photo 1. These findings were in agreement with Ligha et al., (2009), who documented that oral administration of alcohol caused structural alterations in renal tubules, glomerular infiltration by chronic inflammatory cells.

While, rats fed $1 \%$ ginger showed hypertrophy and congestion of glomerular tuft (photo 4), but with 1\% cinnamon vacuolations at renal tubular epithelium were noticed (photo 5). On the other hand, higher supplementations with $2 \%$ of ginger or cinnamon or their mixture groups didn't show any histopathological changes in kidneys of rats (photos $6,7 \&$ 8 ), and that amelioration could be for the anti-inflammatory characteristic of ginger and cinnamon. In consistent, Mahmoud et.al, (2014) reported in-vivo study the effects of dichloromethane extracts of ginger and 
cinnamon in doses of 10 and $20 \mathrm{mg} / \mathrm{kg} /$ day separately on 30 experimentally infected albino rats with Giardia lamblia, one of the most common protozoal, evident revealed improvement for intestinal mucosal damage produced by infection, and showed restoration of normal villous architecture and decrease in inflammatory cells in the lamina propria, these results were more obvious after exposure to cinnamon extracts.

\section{CONCLUSION}

Results could indicate that using powdered ginger and cinnamon may improve retarded kidney functions, modulate liver enzymes activities and improve protein fractions. The mixture of ginger and cinnamon recorded the most beneficial effects and could be used as hypouricemic agent for gout disease.

\section{REFERENCES}

ALGhwij, L.M.; Ghoneim, A. M.; Said, A. E. and AbdAllah, G.A. (2012):

"Effect of Some Herbal Plants on Liver Function of Rats Treated with Trichloroethylene", The Egyptian Journal of Hospital Medicine; Vol. 46, Page 7- 16.

\section{Armitage, P. and Berry, G. (1987): \\ "Statistical Methods in Medical Researc", Blackwell, Oxford, UK, 93-213.}

Askari F.; Rashidkhani B. and Hekmatdoost A. (2014):

Cinnamon may have therapeutic benefits on lipid profile, liver enzymes, insulin resistance, and highsensitivity C-reactive protein in nonalcoholic fatty liver disease patients, Nutr Res., Vol. 34(2), Pp 143-8. 
Barham, D. and Trinder, $P$. (1972) :

"Quantitative enzymatic colorimetric determination of uric acid in serum, plasma or urine ". Analyst, 97: 142.

Campbell, J.A. (1963):

"Methodology of Protein Evaluation, PAG Nutr. Document R. 101 Add. 37, June, Meeting, New York

Changgui, L.; Ming-Chia, $\mathrm{H}$. and Shun-Jen, C. (2013):

"Metabolic syndrome, diabetes, and hyperuricemia". Health and Leisure Studies, National University of Kaohsiung, Kaohsiung, Taiwan, 25 (2); $210-6$

Chapman, D. G.; Castilla, R. and Campbell, J.A. (1959):

Evaluation of protein in food. I.A. Method for the determination of protein efficiency ratio,
Can. J. Biochem, Physiol., 37: 679-686.

Chary, T.M. and Sharma H. (2004):

Bacterial Biochemistry for Medical and Dental Student, Jaypee Brothers Medical Publishers (p) LTD, New Delhi.

Chyntiadewi, M, P. (2011):

"Potential Experiment

Ginger's Rhizome

(Zingiber officinale)

Infusum with

Decreasing Uric Acid Level in Rats (Rattus norwegicus)

Hyperuricemia

Experimental", Medical Faculty of Airlangga University, Surabaya, Indonesia, 79-2.

Drupt, F. (1974):

"Colorimetric method for determination of albumin." Pharm. Biol., 9: 777-779.

Drury, $R$.A. and Wallington, E.A. (1980): 
Walaa I.M. Aniess

"Carton's Histological

Technique". 5th Ed.,

Oxford University, UK

Faller, J. and Fox, I.H. (1982):

Ethanol-induced

hyperuricemia: evidence

for increased urate

production by activation

of adenine nucleotide

turnover. N Engl J Med

307, 1598-1602

Faulkner, N.R. and King, J.W. (1976):

"Fundamental of

Clinical Chemistry".

2nd Ed. Tietz Editor,

Saunders Philadelphia, 994-998

Fossati, P.; Prencipe, L. and Berti , G. (1980) :

"Enzymatic colorimetric method for determination of uric acid in serum". Clin. Chem., 26 (2) : 227-273.

Giner M. and Meguid MM.(1993):

Effect of intragastric and intravenous ethanol on food intake in rats,
Physiol Behav, (54); 2:

399-401

Hamidpour, R.; Hamidpour, M.; Hamidpour, S. and Shahlari, M. (2015):

Cinnamon from the selection of traditional applications to its novel effects on the inhibition of angiogenesis in cancer cells and prevention of Alzheimer's disease, and a series of functions such as antioxidant، anticholesterol, antidiabetes, antibacterial, antifungal, nematicidal، acaracidal, and repellent activities, Journal of Traditional and Complementary Medicine, vol. 5, Pp $66 \mathrm{e} 70$.

Hegested, D.M., Briggs, G.M., Elvehjem, C.A. and Hart, E.B. (1941):

The role of arginine and glycine in chick nutrition. J. Biol. Chem., 140:191-200. 
Walaa I.M. Aniess

Heinig, M. and Johnson, R.J. (2006):

Role of uric acid in hypertension, renal disease, and metabolic syndrome, Cleveland Clinic Journal of Medicine, (12); 73: 1059-64.

\section{Iroaganachi, M.1.; Eleazu,} C. and Okafor, P. (2015) :

Effect of Unripe Plantain (Musa paradisiaca) and Ginger (Zingiber officinale) on Renal Dysfunction in Streptozotocin-Induced Diabetic Rats, JOP., Vol. 20;16(2):167-70.

Jerome, B.; Elyett, G.; Edmond, R.; Andrzej, M. and Yves, R.(2002):

"Substituting honey for refined $\mathrm{CHO}$ protects rats from hypertriglyceridemic and prooxidative effects of fructose". J. Nutr.France, P. 55-65.
Kanani, H.G.; Nobahar, Z.; Kakoolaki, S.; Jafarian, H (2 014):

Effect of ginger- and garlic-supplemented diet on growth performance, some hematological parameters and immune responses in juvenile Huso huso, Fish Physiol Biochem., Vol. 40(2):481-90.

Kaplan, A. (1984):

Urea. Clin. Chem., the C.V. Mosby Co. St., Louis Toronto, Princeton ;1257-1260 and 437- 418.

Kim, H.W.; Murakami, A.; Abe, M.; Ozawa, Y.; Morimitsu, Y.; Williams, M.V.and Ohigashi, H.(2005):

Suppressive effects of mioga ginger and gingerconstituents on reactive oxygen and nitrogen species generation, and the expression of inducible pro-inflammatory genes 
in macrophages", Antioxid Redox Signal, 7: 1621-1629.

Klesges, R.C.; Mealer, C.Z. and Klesges, L.M. (1994):

Effects of alcohol intake on resting energy expenditure in young women social drinkers, Am. J. Clin. Nut., vol. 59(4), 805-9.

Ligha, A.e.; Jaja-Bnr and Numbere, N.f. (2009):

Protective Effect of Abrus Precatorius Seed Extract following Alcohol Induced Renal Damage, European Journal of Scientific Research. Vol. (25); 3: 428-436

\section{Liu ,C.T.; Raghu ,R.; Lin} ,S.H.; Wang ,S.Y.; Kuo, C.H.; Tseng, Y. J. and Sheen, L.Y.(2013):

Metabolomics of ginger essential oil against alcoholic fatty liver in mice". J. Agric. Food
Chem., 61(46):1123140.

Mahmoud A.; Attia, R.; Said, S. and Ibraheim, Z. (2014):

Ginger and cinnamon: can this household remedy treat giardiasis? Parasitological and histopathological studies, Iran J. Parasitol, vol. 9(4):530-40.

Mahmoud, M., F.; Diaai, A.A. and Ahmed, F. (2012):

"Evaluation of the Efficacy of Ginger, Arabic Gum and Boswellia in Acute and Chronic Renal Failure. " Informa Healthcare USA, Inc., 34(1): 73-82.

Mathew, S. and Abraham, T.E. (2006):

Studies on the antioxidant activities of cinnamon

(Cinnamomum verum) bark extracts, through various in vitro models 
", Food Chemistry; 94:520-528.

Moselhy, S. and Ali, $\mathrm{H}$. (2009):

"Hepatoprotective effect of Cinnamon extracts against carbon tetrachloride induced oxidative stress and liver injury in rats." Biol. Res .42: 93-98.

Oso, A.O.; Awe, A.W.; Awosoga, F.G.; Bello, F.A.; Akinfenwa, T.A. and Ogunremi, E.B. ( 2013) :

Effect of ginger (Zingiber officinale Roscoe) on growth performance, nutrient digestibility, serum metabolites, gut morphology, and microflora of growing guinea fowl, Trop Anim Health Prod., Vol. 45(8), Pp1763-9.

Pacher, P.; Nivorozhkin, A. and Szabó, C. (2006):

Therapeutic effects of xanthine oxidase inhibitors: renaissance half a century after the discovery of allopurinol . Pharmacol. (58); 1: 87114.

Proctor, P. (1970):

Similar functions of uric acid and ascorbate in man. Nature (5274); 228: 868 .

Reitman, S. and Frankel, S. (1957):

A colorimetric method for the determination of serum glutamic oxaloacetic and glutamic pyruvic transaminases. Am. J. Clin. Path. , 28: 56.

Roy, S.E. (1970):

"Colorimetric determination of serum alkaline phosphatase", Clin. Chem., 16:431-32.

Sabina, E.P.; Pragasam, S.J.; Kumar, S. and Rasool M. (2011):

6-gingerol, an active ingredient of ginger, 
protects acetaminopheninduced hepatotoxicity in mice, Zhong Xi Yi Jie He Xue Bao., Vol. 9(11):Pp 1264-9.

Saravanan, G.; Tanomand, Ponmurugan, P.; Deepa,
A.M. and Senthilkumar, B. (2014):

" Anti-obesity action of gingerol; effect on lipid fractions, insulin, leptin, amylase and lipase in male obese rats induced by a high-fat diet", Journal of the Science of Food and Agriculture, Article first published online: 7 APR 2014.

Shalaby, M.A. and Saifan, H.Y. (2014):

Some pharmacological effects of cinnamon and ginger herbs in obese diabetic rats, J Intercult Ethnopharmacolv.3 (4); 144-149.

Sonnenwirth, A. and Jaret, L. (1980):
Grad wholes clinical Laboratory Methods and Diagnosis.Vol.18th Ed Mosby, London 258259.

Najafian,M.(2013):

"Inhibitory Effects of

Cinnamon Extract on

Gentamicin-Induced

Nephrotoxicity in Mail Adult Wistar Rats." Advances in Environmental Biology, 7(9): 2100-2104.

Tariq j., khuram s., Irfan, siddique1 and Cagiola (2008):

Effects of ethanol on different organs and on fcr in quails, Pakistan vet. j., 28(3): 119-124.

Tausche, A.K., Unger, S. and Richter, $K$. (2006): Hyperurikämie und Gicht [Hyperuricemia and gout: diagnosis and therapy]. Der Internist. (5); 47: 509-20. 
Walaa I.M. Aniess

Tetsuya, Y.; Moriwaki, Y. and Takahashi, S. (2005):

"Effect of ethanol on metabolism of purine bases hypoxanthine, Xanthinem and uric acid". Clinical chemical acta.(356);1-2:35-57.

Vaibhavi, J.; Rakesh, P.; Pankaj, K. and Neeraj, P.; Sunil, G.; Anupriya, P. and Sonu, S. (2010):

"Cinnamon: a

Pharmacological

Review", J.Adv.Sci.Res, 1(2); 19-23.

Vangalapati, M.; Satya, S.; Prakash, S. and Avanigadda, S. (2012):

A Review on

Pharmacological

Activities and Clinical effects of Cinnamon Species", Research Journal of

Pharmaceutical, Biological and Chemical Sciences.3 (1): 653-661.
Vitart, V.; Rudan, I. and Hayward, C. (2008):

SLC2A9 is a newly identified urate transporter influencing serum urate concentration, urate excretion and gout, Nature Genetics, (4); 40: 437- 42 .

Wang, S.; Yang, C.; Liao, J.; Zhen, W.; Chu, F. and Chang, S. (2008):

"Essential oil from leaves of Cinnamomum osmophloeum acts as a xanthine oxidase inhibitor and reduces the serum uric acid levels in oxonate-induced mice. "Phytomedicine., 15(11):940-5.

Yuri Y. Sautin, Witcha Imaram, Kyung Mee Kim, Alexander Angerhofer, George Henderson and Richard Johnson.(2011):

Uric Acid and Oxidative Stress, Springer Science, Part 2, 143-159. 
Table (1): Effect of cinnamon and ginger on body weight gain (BWG \%) and feed efficiency ratio (FER) of hyperuricemic rats

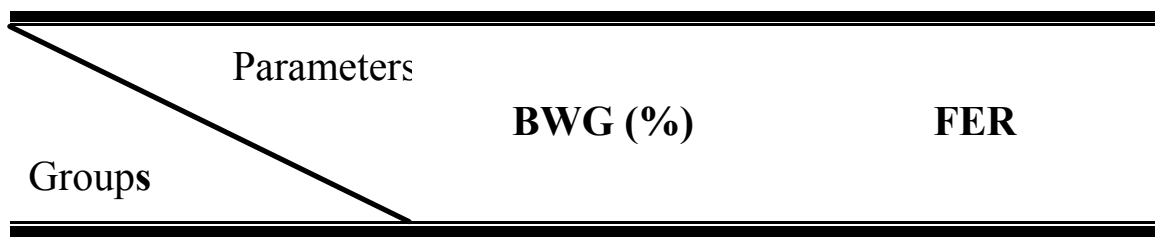

Control (- ve)

$9.1 \pm 2.15^{\mathrm{a}}$

$\mathbf{0 . 9 3 2} \pm 0.04^{\mathrm{a}}$

Control (+ ve)

$5.4 \pm 1.89^{b c}$

$\mathbf{0 . 3 3 7} \pm 0.02 \mathrm{bc}$

Ginger (1\%)
$\mathbf{2 . 5} \pm 0.39^{\mathrm{cd}}$
$\mathbf{0 . 1 2 9} \pm 0.02^{\mathrm{c}}$

Cinnamon (1\%)

$\mathbf{- ~ 6 . 4} \pm 1.55^{\mathrm{e}} \quad \mathbf{- 0 . 7 7 4} \pm 0.03^{\mathrm{de}}$

Ginger (2\%)

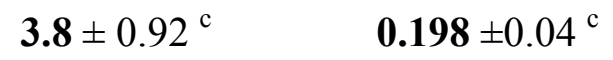

Cinnamon (2\%)

$\mathbf{- 7 . 5} \pm 1.38^{\mathrm{e}} \quad \mathbf{- 0 . 9} \pm 0.04^{\mathrm{de}}$

\section{Mixture of Ginger}

and Cinnamon $\quad \mathbf{- 2 . 3} \pm 0.84^{\mathrm{d}} \quad \mathbf{- 0 . 3 2 3} \pm 0.03^{\mathrm{d}}$ $(1+1 \%)$

- Values are expressed as mean \pm SD.

- Significance is expressed at $\mathrm{p}<0.05$ using one way ANOVA test.

- Values with different letters in each column have differed significantly, while the difference among those with similar letters completely or partially is not significant. 
Table (2): Effect of cinnamon and ginger on relative organs' weight of hyperuricemic rats

\section{Relative Weight}

parameters

Liver Heart Kidneys

Groups

\begin{tabular}{|c|c|c|c|}
\hline Control (- ve) & $\begin{array}{c}\mathbf{3 . 0 9 8}^{\text {de }} \\
\pm 0.170\end{array}$ & $\begin{array}{l}\mathbf{0 . 3 4 3}^{\mathbf{d}} \\
\pm 0.030\end{array}$ & $\begin{array}{l}\mathbf{0 . 6 2 0}{ }^{\mathrm{cd}} \\
\pm 0.052\end{array}$ \\
\hline \multirow{2}{*}{ Control (+ ve) } & $4.600^{a}$ & $0.570^{\mathrm{a}}$ & $1.55^{\mathrm{a}}$ \\
\hline & \pm 0.447 & \pm 0.057 & \pm 0.11 \\
\hline \multirow[t]{2}{*}{ Ginger (1\%) } & $3.966^{b}$ & $0.450^{b c}$ & $1.167^{\mathrm{ab}}$ \\
\hline & \pm 0.151 & \pm 0.055 & \pm 0.082 \\
\hline \multirow[t]{2}{*}{ Cinnamon (1\%) } & $3.517^{c}$ & $0.495^{b}$ & $1 \ldots b$ \\
\hline & \pm 0.194 & \pm 0.039 & $\pm \cdot . \wedge 9$ \\
\hline \multirow[t]{2}{*}{ Ginger (2\%) } & $3.717^{b c}$ & $0.375^{d}$ & $0.955^{b}$ \\
\hline & \pm 0.147 & \pm 0.040 & \pm 0.087 \\
\hline \multirow[t]{2}{*}{ Cinnamon (2\%) } & $3.432^{c d}$ & $0.485^{b}$ & $0.916^{b c}$ \\
\hline & \pm 0.139 & \pm 0.019 & \pm 0.683 \\
\hline \multirow{2}{*}{$\begin{array}{l}\text { Mixture of Ginger } \\
\text { and Cinnamon } \\
(1+1 \%)\end{array}$} & $3.367^{d}$ & $0.351^{d}$ & $0.800^{c}$ \\
\hline & \pm 0.163 & \pm 0.029 & \pm 0.071 \\
\hline
\end{tabular}

- Values are expressed as mean \pm SD.

- Significance is expressed at $\mathrm{p}<0.05$ using one way ANOVA test.

- Values with different letters in each column have differed significantly, while the difference among those with similar letters completely or partially is not significant. 
Table (3): Effect of cinnamon and ginger on uric acid, blood urea nitrogen, urea and creatinine of hyperuricemic rats

\begin{tabular}{|c|c|c|c|}
\hline Parameters & $\begin{array}{c}\text { Uric } \\
\text { Acid(mg/dl) }\end{array}$ & $\begin{array}{c}\text { Urea } \\
(\mathrm{mg} / \mathrm{dl})\end{array}$ & $\begin{array}{l}\text { Creatinine } \\
\text { (mg/dl) }\end{array}$ \\
\hline \multirow{2}{*}{ Control (- ve) } & $1.61^{b}$ & $30.8^{\text {cd }}$ & $0.52^{c}$ \\
\hline & \pm 0.19 & \pm 2.14 & \pm 0.07 \\
\hline \multirow{2}{*}{ Control $(+$ ve $)$} & $2.2^{a}$ & $38.33^{a}$ & $1.21^{\mathrm{a}}$ \\
\hline & \pm 0.08 & \pm 4.47 & \pm 0.08 \\
\hline \multirow[t]{2}{*}{ Ginger (1\%) } & $1.4^{b}$ & $35.4^{\mathrm{b}}$ & $0.65^{b c}$ \\
\hline & \pm 0.07 & \pm 1.8 & \pm 0.05 \\
\hline \multirow[t]{2}{*}{ Cinnamon (1\%) } & $1.58^{b}$ & $31.6^{\mathrm{cd}}$ & $0.78^{b}$ \\
\hline & \pm 0.21 & \pm 3.88 & \pm 0.16 \\
\hline \multirow[t]{2}{*}{ Ginger (2\%) } & $1.4^{b}$ & $34.6^{b c}$ & $0.78^{b}$ \\
\hline & \pm 0.32 & \pm 3.01 & \pm 0.12 \\
\hline \multirow[t]{2}{*}{ Cinnamon (2\%) } & $1.48^{b}$ & $33.8^{\text {bed }}$ & $0.62^{b c}$ \\
\hline & \pm 0.26 & \pm 3.45 & \pm 0.12 \\
\hline \multirow{2}{*}{$\begin{array}{l}\text { Mixture of Ginger } \\
\text { and Cinnamon } \\
(1+1 \%)\end{array}$} & $1.28^{c}$ & $28.4^{d}$ & $0.66^{b c}$ \\
\hline & \pm 0.28 & \pm 1.82 & \pm 0.17 \\
\hline
\end{tabular}

- Values are expressed as mean \pm SD.

- Significance is expressed at $\mathrm{p}<0.05$ using one way ANOVA test.

- Values with different letters in each column have differed significantly, while the difference among those with similar letters completely or partially is not significant. 
Table (4): Effect of cinnamon and ginger on the activity of liver enzymes of hyperuricemic rats

\begin{tabular}{|c|c|c|c|}
\hline Parame & ALT U/L & AST $\mathbf{U} / \mathbf{L}$ & ALP U/L \\
\hline Control (- ve) & $\begin{array}{l}\mathbf{2 2 . 1}^{\text {cd }} \\
\pm 6.67\end{array}$ & $\begin{array}{l}\mathbf{2 2 . 1}^{\mathbf{b c}} \\
\pm 3.713\end{array}$ & $\begin{array}{c}\mathbf{4 6 3 . 7}^{\mathbf{b c}} \\
\pm 66.18\end{array}$ \\
\hline Control $(+$ ve $)$ & $\begin{array}{r}\mathbf{3 5 . 5 7 ^ { \mathrm { a } }} \\
\pm 3.06\end{array}$ & $\begin{array}{l}27.57^{\mathrm{a}} \\
\pm 4.399\end{array}$ & $\begin{array}{c}\mathbf{6 2 5 . 7 7}^{\mathbf{a}} \\
\pm 106.9\end{array}$ \\
\hline Ginger (1\%) & $\begin{array}{c}\mathbf{1 9}^{\mathrm{d}} \\
\pm 2.23\end{array}$ & $\begin{array}{l}\mathbf{2 3 . 6 5}^{\text {bc }} \\
\pm 4.562\end{array}$ & $\begin{array}{c}\mathbf{5 4 9 . 1}^{\mathbf{a b}} \\
\pm 118.3\end{array}$ \\
\hline $\begin{array}{l}\text { Cinnamon } \\
(1 \%)\end{array}$ & $\begin{array}{l}\mathbf{2 9 . 5} \mathbf{b}^{\mathbf{b}} \\
\pm 4.93\end{array}$ & $\begin{array}{l}\mathbf{2 3 . 3}^{\mathbf{b c}} \\
\pm 4.774\end{array}$ & $\begin{array}{c}\mathbf{4 9 4 . 5} \mathbf{5}^{\text {abc }} \\
\pm 105.7\end{array}$ \\
\hline Ginger (2\%) & 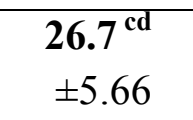 & $\begin{array}{c}\mathbf{2 5 . 7}^{\mathbf{b}} \\
\pm 6.269\end{array}$ & $\begin{array}{l}\mathbf{4 6 0 . 1}^{\text {bc }} \\
\pm 133.3\end{array}$ \\
\hline $\begin{array}{l}\text { Cinnamon } \\
(2 \%)\end{array}$ & 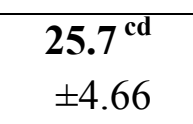 & $\begin{array}{l}\mathbf{2 1 . 1} \mathbf{b}^{\mathrm{bc}} \\
\pm 3.561\end{array}$ & $\begin{array}{l}\mathbf{4 2 5 . 1}^{\mathrm{bc}} \\
\pm 134.5\end{array}$ \\
\hline $\begin{array}{l}\text { Mixture of } \\
\text { Ginger and } \\
\text { Cinnamon } \\
(1+1 \%)\end{array}$ & $\begin{array}{l}22^{\text {cd }} \\
\pm 3.5\end{array}$ & $\begin{array}{l}19.3^{\mathrm{c}} \\
\pm 2.14\end{array}$ & $\begin{array}{l}\mathbf{3 6 4 . 9}^{\mathrm{c}} \\
\pm 101.2\end{array}$ \\
\hline
\end{tabular}

- Values are expressed as mean \pm SD.

- Significance is expressed at $\mathrm{p}<0.05$ using one way ANOVA test.

- Values with different letters in each column differed significantly, while the difference among those with similar letters completely or partially is not significant. 
Table (5): Effect of cinnamon and ginger on serum proteins (T.P, Alb and Glb ) of hyperuricemic rats

\begin{tabular}{llll}
\hline & T.P $\mathrm{mg} / \mathrm{dl}$ & Alb $\mathrm{mg} / \mathrm{dl}$ & Glb $\mathrm{mg} / \mathrm{dl}$ \\
\hline & & & \\
\hline
\end{tabular}

- $\quad$ Values are expressed as mean \pm SD.

- Significance is expressed at $\mathrm{p}<0.05$ using one way ANOVA test.

- Values with different letters in each column differed significantly, while the difference among those with similar letters completely or partially is not significant. 


\section{- Kidney}

\begin{tabular}{|c|c|}
\hline $\begin{array}{l}\text { a } \\
\text { Photo (1): Kidney of rat from negative } \\
\text { control group showing the norma } \\
\text { histological structure of rena } \\
\text { parenchyma (H \& } E X \text { 400). }\end{array}$ & $\begin{array}{l}\text { } \\
\text { Photo (2): Kidney of rat from positive } \\
\text { control group showing vacuolation of } \\
\text { renal tubular epithelium and } \\
\text { perivascular inflammatory cells } \\
\text { infiltration }(\mathrm{H} \& \mathrm{E} \times \mathbf{4 0 0} \text { ). }\end{array}$ \\
\hline $\begin{array}{l}\text { Photo (3): Kidney of rat from positive } \\
\text { control group showing protein cast in the } \\
\text { lumen of renal tubules }(\mathrm{H} \& \mathrm{E} \times \mathbf{4 0 0}) \text {. }\end{array}$ & $\begin{array}{l}\text { Shoto (4): Kidney of rat fed on ginge } \\
\text { Photo } \\
1 \% \text { showing hypertrophy and } \\
\text { congestion of glomerular tuft (H \& E X } \\
\text { 400). }\end{array}$ \\
\hline
\end{tabular}


Con

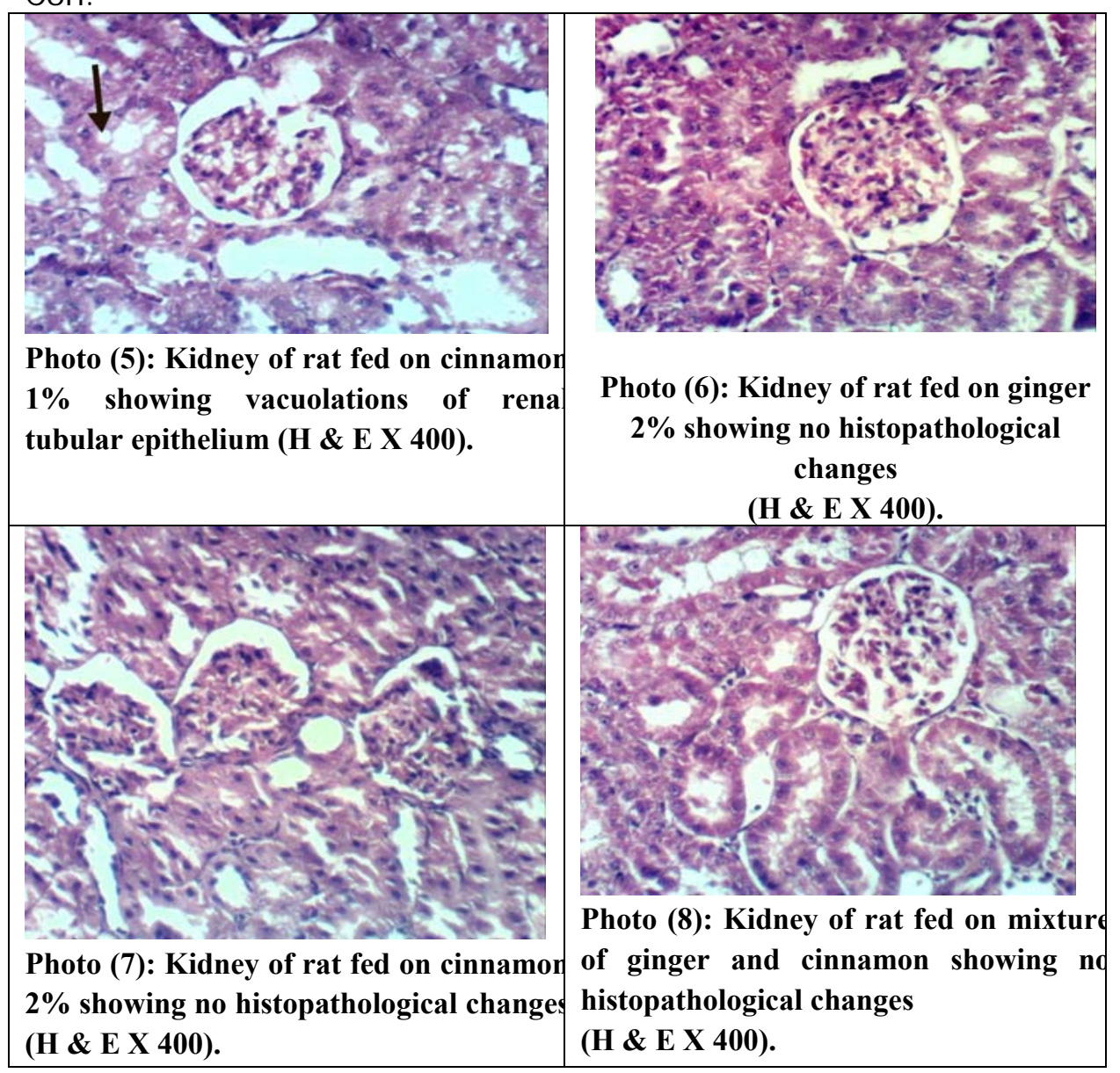




\section{تأثير التغذية بيعض الأعشاب على الجرذان

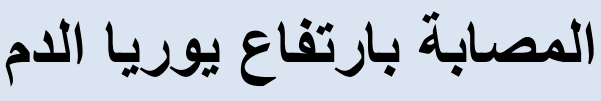 \\ و لاء إبر اهيم محمد أنبس \\ قسم الاقتصاد المنزلي، كلية التربية النوعية، جامعة عين شمس.}

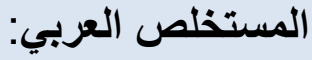

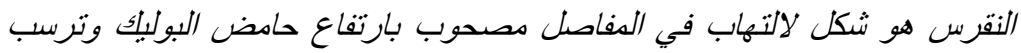

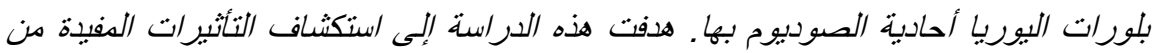

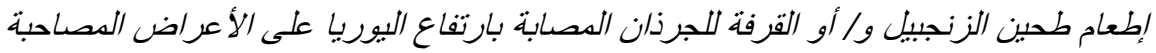

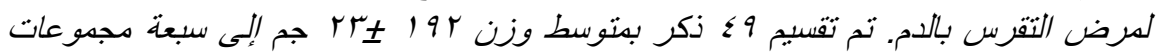

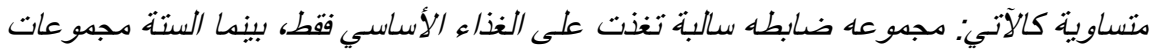

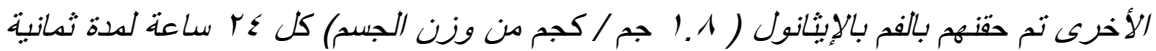

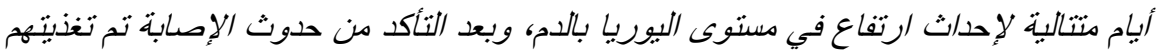

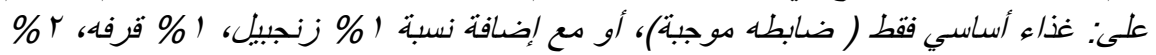

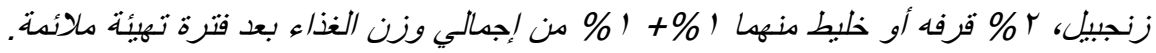

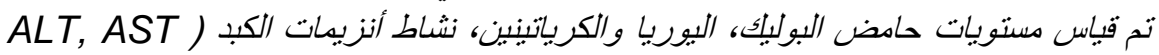
(and ALP

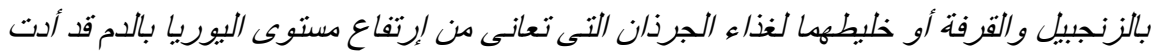

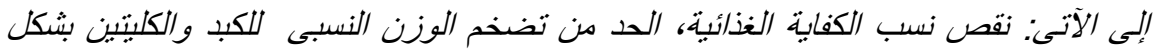

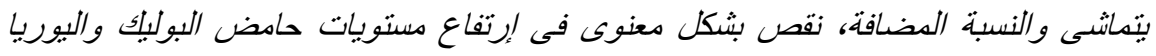
والكرياتينين، الحد من إرتفاع مستويات نشاط إنزبيات الكبد

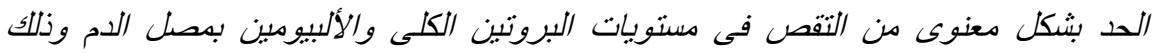

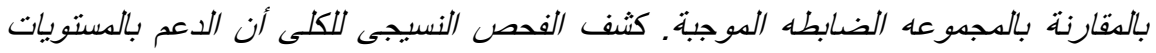

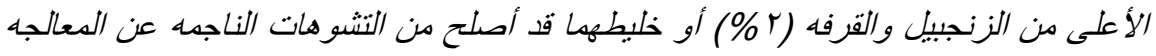

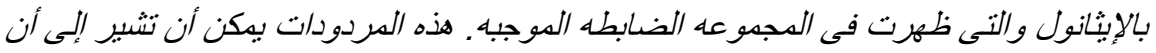

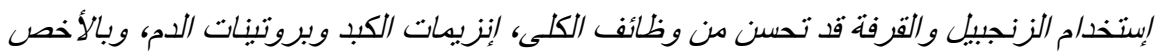

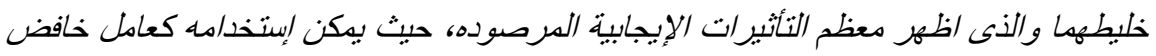
لمستويات اليوريا بالدم فى مرض النه معظم النقرس كعلاج مساعد.

الكلمات المفتاحية. زنجبيل، قرفه، التغذية، إرتفاع يوريا الدم، الجرذان، أنزيمات الكبد، وظائف الكلى وصورة بروتين الدم. 